\title{
Estimation of Anti-proliferative Activity of Saccharin against Various Cancer Cell Lines and MSCs
}

\author{
Jeong Su Choi ${ }^{1}$, Sang Yong Park ${ }^{1}$, Man Gil Yang ${ }^{2}$, Dong Beom Lee ${ }^{3}$, Tae Bok Lee ${ }^{4}$, Ji Hye Heo ${ }^{5}$, \\ Min Woo Lee ${ }^{1}$, Suhng Wook Kim ${ }^{1}$ \\ ${ }^{1}$ Department of Integrated Biomedical and Life Sciences, Graduate School, Korea University, Seoul 02841, Korea \\ Biomedical Research Institute, Seoul National University, Seoul 03080, Korea \\ ${ }^{3}$ Central Blood Laboratory Center, Korea Red Cross, Seoul 07559, Korea \\ ${ }^{4}$ Department of Senior Healthcare, Graduate School, Eulji University, Daejeon 34824, Korea \\ ${ }^{5}$ Department of Clinical Laboratory Science, Donga College of Health, Yeongam 58439, Korea
}

\section{다양한 암세포 주와 MSCs에 대한 Saccharin의 항증식성 평가}

\author{
최정수 ${ }^{1}$, 박상용 $^{1}$, 양만길 $^{2}$, 이동범 ${ }^{3}$, 이태복 ${ }^{4}$, 허지혜 ${ }^{5}$, 이민우 ${ }^{1}$, 김성욱 $^{1}$ \\ ${ }^{1}$ 고려대학교 대학원 의생명융합과학과, ${ }^{2}$ 서울대학교병원 의생명연구원, ${ }^{3}$ 대한적십자사 중앙혈액검사센터, ${ }^{4}$ 을지대학교 대학원 시니어헬스케어학과, \\ 5동아보건대학교 임상병리과
}

\begin{abstract}
Saccharin (o-benzoic sulfimide) is the first artificial and non-caloric sweetener that was first synthesized in 1879. In this study, we examined the biological activity of saccharin against various human cancer cell lines and human bone marrow-derived mesenchymal stem cells. A viability assay based on the conversion of 3-(4,5-dimethylthiazol-2-yl)-2,5-diphenyltetrazolium bromide (MTT) was performed to test for the cytotoxicity of saccharin about the four human cancer cell lines (H460, H157, A549 and SKOV3), one murine cancer cellline (Raw264.7), and MSCs. In order to find the differentially expressed gene in saccharin-treated MSCs against untreated MSCs, we performed annealing control primer (ACP)-based differential display reverse transcriptionpolymerase chain reaction (DDRT-PCR). All tested cells were treated with saccharin at various concentrations $(0.0,4.8,7.2,9.6,12.0,14.4 \mathrm{mg} / \mathrm{mL})$ for $48 \mathrm{hr}$. The number of metabolically active cancer cells decreased when treated with the saccharin at various concentrations for $48 \mathrm{hr}$ as compared with the untreated cells. The decrease in cell survival was more evident with increasing concentrations of saccharin. Moreover, novel candidate genes, which were differentially expressed in MSCs in response to saccharin, were identified in 16 bands on $2 \%$ agarose gel. This revealed $16-$ 7 up-regulated and 9 down-regulated-differentially expressed genes indicated by arrows. One of these candidate genes was a FK506-binding protein gene. The functional roles of FK506 binding proteins, with respect to the activities of stem cell proliferation, were not characterized. Further studies are required to get a better understanding of FK506-binding proteins in its roles in increasing stem cell proliferative activities from using saccharin.
\end{abstract}

Key words: Saccharin, Mesenchymal stem cells, Cancer, Anti-proliferation

This is an Open Access article distributed under the terms of the Creative Commons Attribution Non-Commercial License (http://creativecommons.org/licenses/by-nc/4.0) which permits unrestricted non-commercial use, distribution, and reproduction in any medium, provided the original work is properly cited.

Copyright @ 2016 The Korean Society for Clinical Laboratory Science. All rights reserved.
Corresponding author: Suhng Wook Kim Department of Integrated Biomedical and Life Sciences, Graduate School, Korea University, Seoul 02841, Korea

Tel: 82-2-3290-5686

Fax: 82-2-940-2829

E-mail: swkimkorea@korea.ac.kr

Co-Corresponding author: Min Woo Lee Department of Integrated Biomedical and Life Sciences, Graduate School, Korea University, Seoul 02841, Korea Tel: 82-2-940-2784

Fax: 82-2-940-2829

E-mail: leemw@korea.ac.kr

Received: May 1, 2016 Revised 1t: May 25, 2016 Revised 2 ${ }^{\text {nd }}$ : June 6, 2016 Accepted: June 7, 2016

\section{서 론}

지난수 십 년 동안, 음식의 조리에 활용되는 설탕을 대체하기 위
한 방법에 대한 관심이 소비자와 식품제조회사 양쪽 모두 높아짐에 따라 인공감미료의 사용량은 점차 증가되어 왔다[1,2]. Saccharin (o-benzoic sulfimide)은 1879년에 최초로 합성된 열량이 없는 인 
공감미료이다. Saccharin은 설탕보다 약 300배정도 강한 단맛을 가지고 있다. 따라서, 설탕보다 상당한 잠재력을 가지고 있다. 굉장 히 적은 양으로도 음식이 필요한 만큼의 단맛을 낼 수 있다[3,4]. 특 히, 당뇨병과 고혈당증을 겪고 있는 환자에 있어서, 당질대사에 의 해 생성되는 glucose의 혈중 수준을 조절하는 것은 매우 중요하다. 이런 상황을 고려하여, 몇몇 학자들은 돼지감자나 신령버섯 추출물 등과 같은 혈중 glucose 농도를 낮출수 있는 물질에 대해 관심을 갖 고 있다[5,6]. 이런 상황에서, saccharin은 또 다른 대안이 될 지 모 른다. Saccharin은 통상적으로 sodium과 calcium salt 형태뿐만 아니라 acid 형태로 활용이 가능하다. Saccharin의 가장 일반적으 로 사용되는 형태는 sodium salt 형태이다. 이 모든 saccharin들은 흰색의 무취한 고형 물질이다. Acid 형태의 saccharin은 물에 대한 용해도가 좋지 않은 반면, salt 형태의 saccharin은 매우 높은 물에 대한 용해도를 가지고 있다[3]

Saccharin의 발암성에 대한 무수한 동물실험과 역학조사가 이 루어 지고 있다. 설치류를 대상으로 하여 장기간 동안 saccharin에 노출시켰을 때 나타날 수 있는 발암성에 대한 실험 결과는 Sodium saccharin이 수컷 rat의 방광에 대하여 약한 발암성을 가지는 종양 생성 물질임을 보여준다. 대부분, saccharin이 rat 방광에서 종양 을 일으키는 기전은 수컷 rat 방광의 생리학적인 특이성 때문이다 [7]. Saccharin이 인체 내에서 종양생성과 연관되어 있다는 어떠한 역학적 조사 자료도 존재하지 않으며, 이러한 사실을 바탕으로 sodium saccharin은 결국 인간에 대한 비발암성 물질로 분류되 었다[8]. 1987년, saccharin의 일일 섭취한도는 몸무게 기준으로 $2.5 \mathrm{mg} / \mathrm{kg}$ 로 정해졌다[9]. 후에, 몸무게 기준 $5 \mathrm{mg} / \mathrm{kg}$ 으로 조정 되 었다[10].

하지만, 우리가 알고 있는 것처럼, 암세포와 줄기세포에 saccharin이 미치는 영향에 대한 연구는 거의 진행된 바가 없다. 본 연구에서, 우리는 다양한 인간 암세포주와 인간 골수에서 유래한 중간엽 줄기세포에 대한 saccharin의 생물학적 활성을 실험해보 고자 한다.

\section{재료 및 방법}

\section{1. 실험재료}

세포에 Saccharin을 처리하기 위해 사카린 sodium saccharin (JMC corporation, Seoul, Korea)을 구입하여 사용하였다. 실험에 사용된 인간 골수 유래 중간엽 줄기 세포(MSCS)는 Lonza (Basel, Switzerland)에서 구입하였고, 인간 폐 암세포주 H460, H157, A549 3종과 난소 암세포주 SKOV3, 쥐 암세포주 Raw264.7는 American Type Culture Collection (Manassas, VA)에서 구입하
여 사용하였다.

\section{Cytotoxicity test}

3-(4,5-dimethylthiazol-2-yl)-2,5-diphenyltetrazolium bromide (MTT)의 변환을 기초로 한 세포 viability assay는 세포독 성을 test하기 위해 실행되었고 세포 생존은 노란 tetrazolium salt 가 불용성의 자색 formazan 형태로 변환되는 것을 기초로 하였다. 4가지 인간 암세포주(H460, H157, A549 그리고 SKOV3)와 하나 의 쥐 암세포주(Raw264.7) 그리고 MSCs는 96well plate에 세포 수를 $5 \times 10^{3} \mathrm{cells} / \mathrm{well}$ 의 농도로 분주 하여 세포 부착을 위해 24 시 간 동안 $37^{\circ} \mathrm{C}$ 에서 incubate 후, 48 시간 동안 saccharin 처리를 하 였고 MTT시약(Sigma-Aldrich)을 첨가하여 2시간동안 incubate 시켰다. Incubate 후에 상층액을 제거하고 formazan을 용해시키 기 위해 각 well 마다 dimethylsulfoxide (Sigma-Aldrich)를 첨가 하여 multi-well spectrophotometer를 이용하여 $570 \mathrm{~nm}$ 에서 흡 광도를 측정했다.

\section{Annealing control primer (ACP)-based differential display reverse transcription polymerase chain reaction (DDRT-PCR)}

Saccharin에 대한 반응으로 MSCS에서 특별히 발현되는 의미 있는 새로운 유전자후보 군을 확인하기 위해서 GeneFishing ${ }^{\mathrm{TM}}$ DEG kits (Seegene, Seoul, Korea)를 이용하여 random priming 을 적용한 ACP-based DDRT-PCR을 실시하였고[11], 이를 통해 Differentially Expressed Genes (DEG)에 대한 분석을 실시하였 다. 이를 위해, total RNA를 untreated MSCs, 낮은 농도(7.2 $\mathrm{mg} / \mathrm{mL})$ 의 saccharin으로 처리한 MSCs 그리고 고농도(14.4 $\mathrm{mg} / \mathrm{mL}$ )의 saccharin으로 처리한 MSCs로부터 추출하였고 이 total RNA를 ACP-based DDRT-PCR 분석을 시행하여 얻은 PCR 산물을 2\% agarose gel에 로딩하였다. Untreated MSCs와 saccharin을 처리한 MSCs로부터 추출한 total RNAs를 이용하여 first-strand cDNAs를 합성하는 역전사는 $3 \mu \mathrm{g}$ 의 정제된 total RNA, reaction buffer, 2mM dNTPs, dT-ACP1 (5'-CGTGAATGCTGCGACTACGATIIIIT (18)-3'), RNase Inhibitor (Promega, Madison, WI, USA), 그리고 MMLV reverse transcriptase (Promega)로 구성된 reaction mixture를 구성하여 $42^{\circ} \mathrm{C}$ 에서 1.5 시간 동안 진행하였다. 다음으로 Second-strand $\mathrm{CDNA}$ 를 합 성하기 위해 first-strand cDNA, $1 \mu \mathrm{g}$ 의 $10 \mu \mathrm{M}$ dT-ACP2 (5'-CGTGAATGCTGCGACTACGATIIIIT (15)-3'), $10 \mu \mathrm{M}$ arbitrary ACP primers 그리고 2X Master Mix (Seegene, Seoul, Korea)를 포함한 reaction mixture를 구성하고 합성을 위한 PCR 
protocolo 은 $94^{\circ} \mathrm{C} 1$ 분, 그 다음 $50^{\circ} \mathrm{C} 3$ 분, 그리고 $72^{\circ} \mathrm{C} 1$ 분의 1 cycle로 이루어졌다. Second-strand DNA 합성이 완료 된 후, $\mathrm{PCR}$ 증폭 protocol은 $94^{\circ} \mathrm{C}$ 40초, 그 다음 $65^{\circ} \mathrm{C} 40$ 초, $72^{\circ} \mathrm{C} 40$ 초 의 $40 \mathrm{cycle}$ 과 $72^{\circ} \mathrm{C} 5$ 분동안의 마지막 extension 과정으로 이루어 졌다. 증폭된 PCR 산물은 $2 \%$ agarose gel에 분주하고 ethidium bromide로 염색하고 차별성 있는 band의 유무는 ChemiDoc XRS (Bio-Rad, Hercules, CA, USA)장비를 이용하여 band의 강도를 측 정하여 평가하였다. 차별성이 보인 band는 gel에서 추출하고 TOPO TA cloning vector (Invitrogen, Carlsbad, CA, USA)의 방 법을 이용하여 직접적으로 cloning 실시하였다. 이 clone화 된 plasmids의 염기서열을 밝혀내고 각각의 gene에대한 DNA sequence는 GenBank (NIH, Bethesda, MD, USA)의 sequence 와 비교하여 확인하였다.

\section{4. 통계 처리}

Saccharin 처리하지 않은 세포와 처리한 세포를 비교하기 위해, 모든 세포 독성 실험은 3번 반복하여 실행하였고, 그 결과는 SPSS version 12. 0 통계프로그램(SPSS Inc., Chicago, IL, USA)을 이용 하여 non-parametric kruskal-wallis test를 통해 유의확률 $p<0.05$

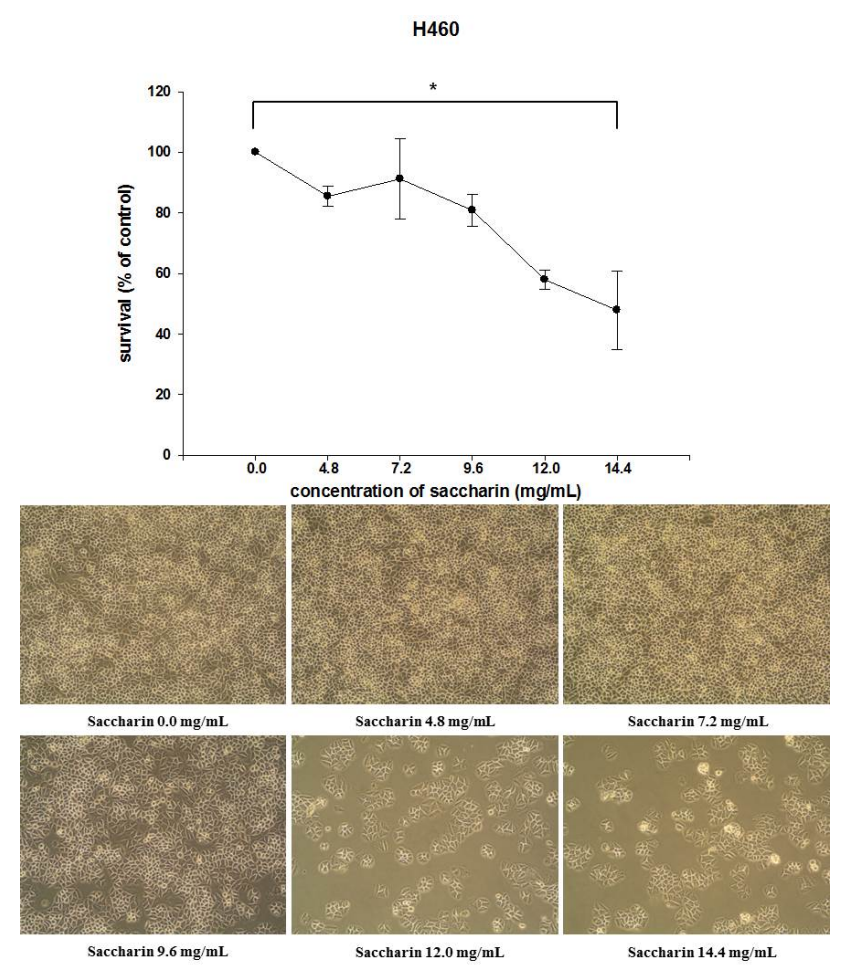

Fig. 1. Effects of saccharin on the proliferation of $\mathrm{H} 460$ cancer cell line. Datum points repesent the mean and error bars from triplicated independent experiments are shown. ${ }^{*}(p<0.05)$ indicates significant statistical difference. $p$-value $=0.013$, kruskal-wallis test.
수준으로 통계적 유의성을 확인하였다.

\section{결 과}

\section{Cytotoxicity test}

Saccharin에 의해 유도된 항증식성 활성은 4가지 인간 암세포 주와 한가지 쥐 암세포주에서 현미경을 통한 직접적인 세포의 검경 과 MTT assay를 활용하여 확인되었다. 실험된 모든 세포는 48시간 동안 다양한 농도의 saccharin $(0.0,4.8,7.2,9.6,12.0,14.4$ $\mathrm{mg} / \mathrm{mL}$ ) 처리를 하였다. Large cell lung carcinoma를 일으키는 H460은 비교적 높은 농도의 saccharin 처리군 $(12.0 \mathrm{mg} / \mathrm{mL}, 14.4$ $\mathrm{mg} / \mathrm{mL}$ )에서 saccharin을 처리하지 않은 세포와 비교하였을 때, 눈에 띄는 세포수의 감소가 현미경을 통해 관찰되었고 통계적으로 도 유의한 감소( $p=0.013)$ 가 확인되었다(Fig. 1). Squamous cell lung carcinoma의 세포인 H157에서도 saccharin 농도의 증가에 따른 세포 수의 감소가 확인되었고, $\mathrm{H} 460$ 과 비슷한 감소 ( $p=0.046$ )경향을 보였다(Fig. 2). Lung adenocarcinoma와 관련 된 A549에서는 현미경상에서는 약간의 세포수 감소가 보이는 듯 했지만(Fig. 3), MTT assay 결과의 통계적 분석 시 유의한 세포수의
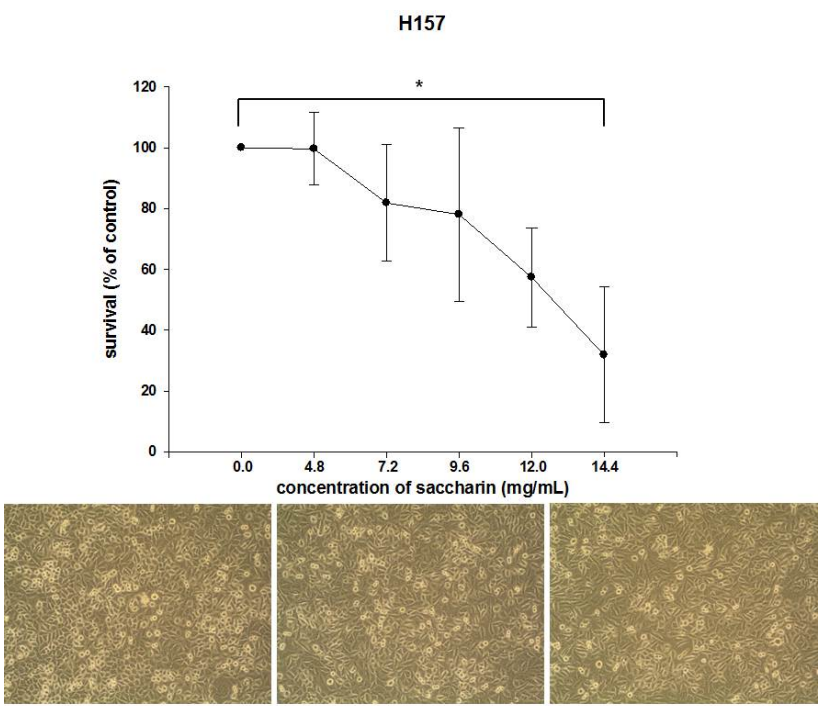

Saccharin $0.0 \mathrm{mg} / \mathrm{mL}$

Saccharin $4.8 \mathrm{mg} / \mathrm{mL}$

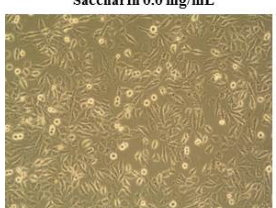

Saccharin $9.6 \mathrm{mg} / \mathrm{mL}$
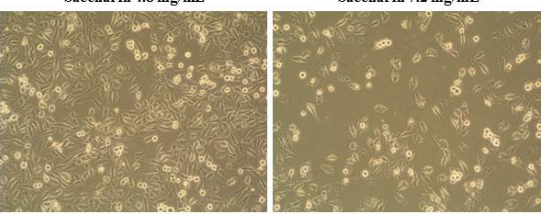

Saccharin $12.0 \mathrm{mg} / \mathrm{mL}$

Saccharin $14.4 \mathrm{mg} / \mathrm{mL}$

Fig. 2. Effects of saccharin on the proliferation of H157 cancer cell line. Datum points repesent the mean and error bars from triplicated independent experiments are shown. ${ }^{*}(p<0.05)$ indicates significant statistical difference. $p$-value $=0.046$, kruskal-wallis test. 


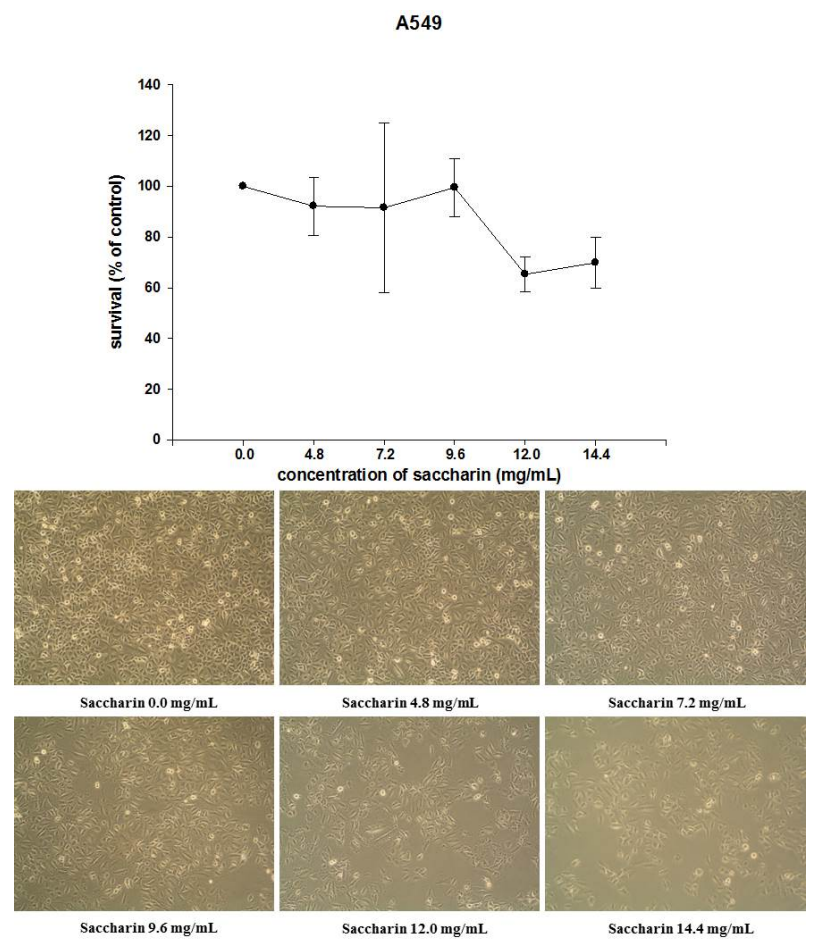

Fig. 3. Effects of saccharin on the proliferation of A549 cancer cell line. Datum points repesent the mean and error bars from triplicated independent experiments are shown. $p$-value $=0.144$, kruskal-wallis test.

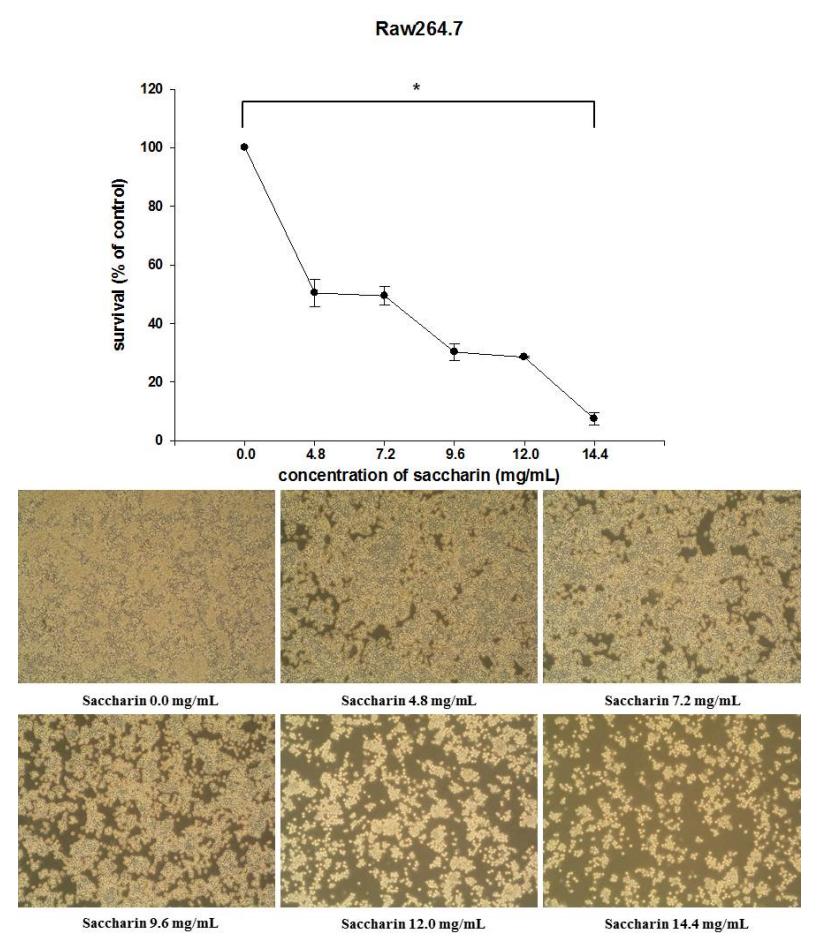

Fig. 4. Effects of saccharin on the proliferation of Raw264.7 cancer cell line. Datum points repesent the mean and error bars from triplicated independent experiments are shown. ${ }^{*}(p<0.05)$ indicates significant statistical difference. $p$-value $=0.008$, kruskal-wallis test.

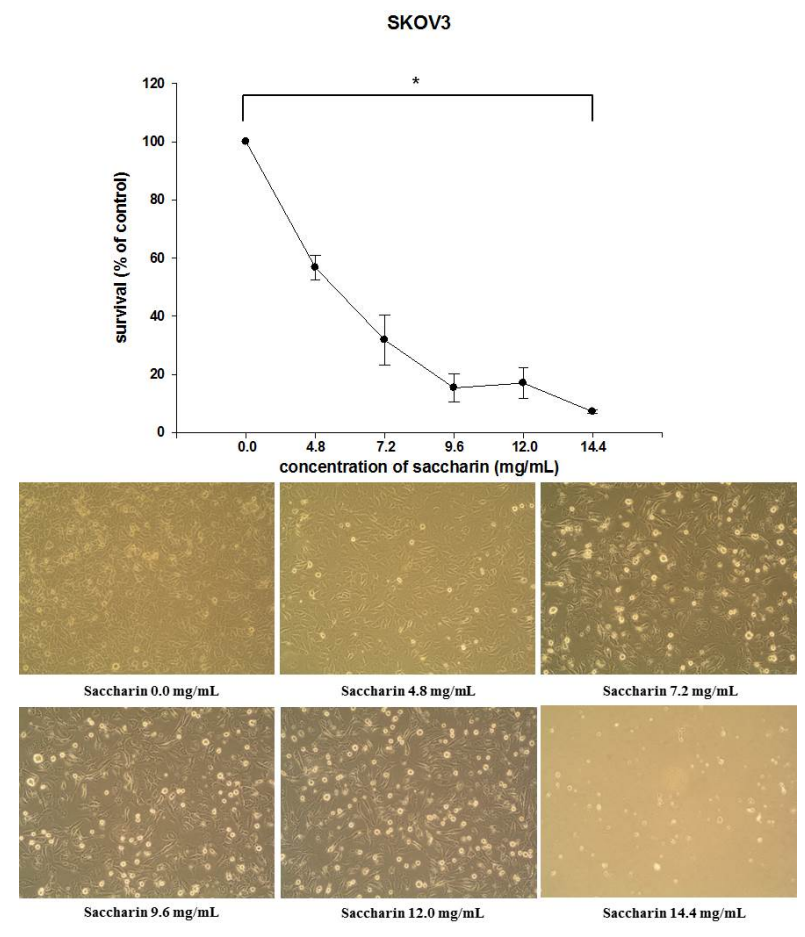

Fig. 5. Effects of saccharin on the proliferation of SKOV3 cancer cell line. Datum points repesent the mean and error bars from triplicated independent experiments are shown. ${ }^{*}(p<0.05)$ indicates significant statistical difference. $p$-value $=0.006$, kruskal-wallis test.

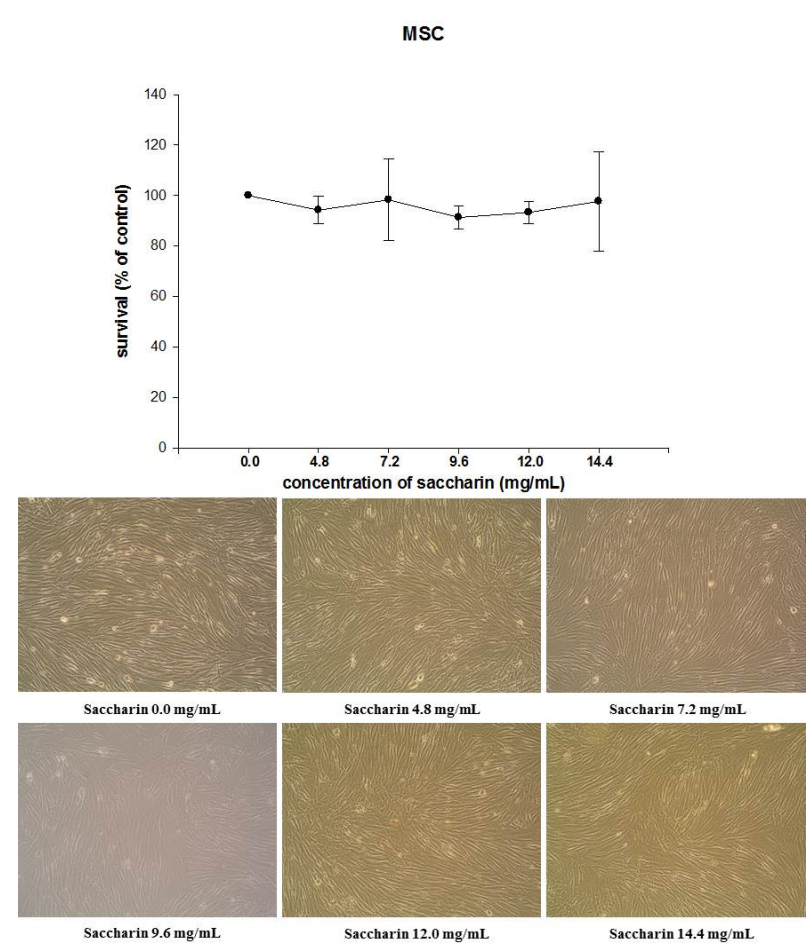

Fig. 6. Effects of saccharin on the proliferation of human bone marrow-derived mesenchymal stem cells. Datum points repesent the mean and error bars from triplicated independent experiments are shown. $p$-value $=0.640$, kruskal-wallis test. 
감소는 보이지 않았다 $(p=0.144)$. 다음으로 Mouse leukemia 세포 인 RAW264.7 실험 결과, 모든 saccharin 처리군에서 확연한 세포 수의 감소가 현미경을 통해 관찰되었고(Fig. 4) saccharin 농도와 cell viability 사이의 높은 유의성을 확인할 수 있었다 $(p=0.008)$. 마지막으로 Ovarian serous cystadenocarcinoma 세포인 SKOV3도 모든 saccharin 처리군에서 control에 비해 대사활성을 지닌 세포수의 유의한 감소 $(p=0.006)$ 가 관찰되어 saccharin에 대 해 높은 감수성을 보였다(Fig. 5). 하지만, saccharin은 인간 골수 유래 중간엽 줄기세포(MSCs)에 대해 어떤 세포 damage도 유발하 지 않는 것으로 보인다. 다양한 농도의 saccharin처리를 한 인간 골 수 유래 MSCs에 대한 MTT assay를 실행했을 때, 인간 골수 유래 $\mathrm{MSC}$ 의 생존 능력은 saccharin을 처리하지 않은 세포에 비해 줄어 들지 않았고 $(p=0.640)$ 현미경을 통해 확인한 세포의 모습에서도 눈에 띄는 차이가 발견되지 않았다(Fig. 6).

\section{Annealing control primer (ACP)-based differential} display reverse transcription polymerase chain reaction (DDRT-PCR)

ACP based DDRT-PCR 후 Up-regulated 되거나 down-regulated된 gene들을 확인하기 위해 실시한 $2 \%$ agarose gel 전기영 동을 실시한 결과, 고농도( $14.4 \mathrm{mg} . \mathrm{mL})$ 의 saccharin 처리 MSCs

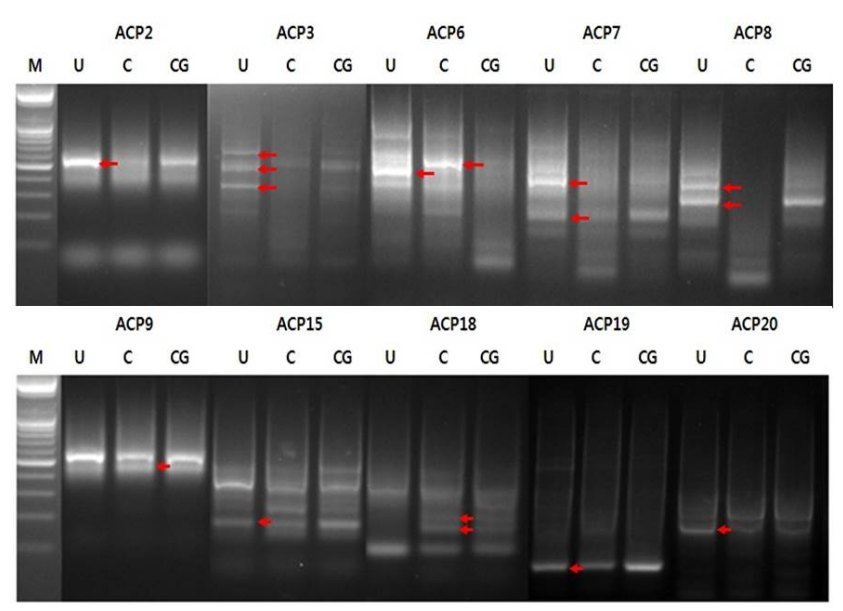

Fig. 7. Detection of differentially expressed genes in MSCs treated with saccharin. Total RNA was extracted from MSCs treated with saccharin and subjected to ACP-based DDRT-PCR. Twenty arbitrary ACP primers (ACP1 to ACP20) were used to isolate the differentially expressed genes. Differential expression patterns were observed when the arbitrary ACP primer sets (indicated on the top) were used. The arrows on the right-hand side indicate differential expressed bands between untreated MSCS (U) and low concentration $(7.2 \mathrm{mg} / \mathrm{mL})$ of saccharin-treated MSCs (C) and high concentration $(14.4 \mathrm{mg} / \mathrm{mL})$ of saccharin-treated MSCs (CG). M, 100-bp NA ladder.
에서 untreated MSCs와 저농도( $7.2 \mathrm{mg} / \mathrm{mL})$ 의 saccharin 처리 $\mathrm{MSC}$ 와 다른 16개의 차별성 있게 발현된 gene들이 보였고 그 중 7 개의 up-regulated gene과 9 개의 down-regulated gene이 나타 났다(Fig. 7). 이 gene들을 gel에서 분리, 정제하고 clone화 하여 sequence를 분석하였고 GenBank의 BLAST search를 통해 이 발 현차이가 나는 gene들과 가장 유사성이 높은 기존에 알려진 gene sequence를 찾을 수 있었고, 이를 Table 1에 요약하였다.

\section{고 찰}

MTT assay를 통해 확인한 saccharin의 항증식성 활성은 세포 주의 종류에 따라 약간의 차이가 있는 것으로 나타났지만, 실험된 모든 암세포들은 48시간 동안 다양한 농도의 saccharin으로 처리 된 후, saccharin 처리하지 않은 control 세포보다 대사활성을 지 닌 세포의 수가 감소하는 것을 확인할 수 있었고, 대체로 처리한 saccharin의 농도가 증가함에 따라 이런 세포의 대사활성 감소가 더욱 두드러지는 것으로 보였다. 또한, 현미경을 통한 세포의 형태 확인을 병행한 결과, Saccharin 처리를 하지 않은 control plate에 비해 고농도의 saccharin으로 처리한 plate에서 정상적인 모양을 갖추지 못하거나 안정적으로 부착을 하지 못하고 부유하는 세포들 이 더 두드러지게 발견되는 것으로 보아 실험에 이용된 농도 범위 의 saccharin은 암세포에 대한 세포독성을 가지고 있는 것으로 확 인되었다. 이에 반해, 인간 골수 유래 $\mathrm{MSCs}$ 를 대상으로 한 saccharin의 세포독성 실험에서는 MTT assay 결과 통계적으로 유 효한 세포대사활성의 감소를 확인할 수 없었고, 현미경 상으로도 눈에 띄는 비정상적인 세포의 형태나 세포의 불안정한 부착 또는 세포의 부유는 관찰되지 않았다. Saccharin의 발견이래로, 인공적 으로 합성된 열량이 없는 감미료의 사용은 잠재적 독성 효과를 걱 정하는 수많은 논란의 중심에 서고 있다. 지금까지 우리의 지식에 의하면, 인간 골수 유래 MSCs에 대한 saccharin의 효과를 명시하 고 있는 문서는 없다. 본 연구에서 우리는 saccharin과 함께 배양한 인간 골수 유래 $\mathrm{MSCs}$ 가 어떤 독성 효과 영향 받지 않고 안정적인증 식 활성을 지닌 것을 확인할 수 있었다.

ACP based DDRT-PCR 실험으로 16개의 발현차이를 보이는 gene을 선별하였으며 이 중 가장 뚜렷한 발현차이를 보이는 gene 은 $\mathrm{ACP} 2$ 에서 증폭된 gene으로 이 gene의 분리, 정제 후 sequencing한 결과, FK506 binding protein gene과 상당히 유사 한 것으로 나타났다(Fig. 7, Table 1). 이 FK506-binding proteins 은 일차적으로 FK506과 면역 억제제에 이용되는 토양 bacteria에 의해 생성되는 macrolides과 같은 rapamycin의 세포 내 target이 다[12,13]. 이 FK506-binding proteins은 immunophilins으로 
Table 1. Sequence similarities of differentially expressed genes

\begin{tabular}{|c|c|c|}
\hline Clone Name* & Identity & GenBank Accession No. \\
\hline ACP $2(d n)$ & Homo sapiens mRNA for FK506 binding protein 9 variant protein & AB209352 \\
\hline ACP 3-1 (dn) & Homo sapiens eukaryotic translation initiation factor $4 \mathrm{~A}$, isoform 1 , mRNA & BC009585 \\
\hline ACP 3-2 (dn) & Homo sapiens eukaryotic translation initiation factor $4 \mathrm{~A}$, isoform 1 , mRNA & BC009585 \\
\hline ACP 3-3 (dn) & Homo sapiens genomic DNA, chromosome 11q clone:RP11-109L13, complete sequences & AP005018 \\
\hline ACP 6-1 (dn) & Human cytoplasmic beta-actin gene & M10277 \\
\hline ACP 6-2 (dn) & Homo sapiens exocyst complex component 3, mRNA & BC064569 \\
\hline ACP $7-1(\mathrm{dn})$ & Homo sapiens ubiquinol-cytochrome c reductase, complex III subunit VII, 9.5 kDa, mRNA & BC090048 \\
\hline ACP 7-2 (up) & Homo sapiens mRNA for PRP8 protein & AB007510 \\
\hline ACP 8-1 (dn) & Homo sapiens mRNA for endoplasmic reticulum chaperone (SIL1 gene) & Al2S \\
\hline ACP 8-2 (up) & Homo sapiens mRNA; cDNA DKFZp586J021 (from clone DKFZp586J021) & AL110197 \\
\hline ACP 9 (up) & Homo sapiens TIMP metallopeptidase inhibitor 1 (TIMP1) & NM_003254 \\
\hline ACP 15-1 (up) & Homo sapiens membrane bound 0 -acyltransferase domain containing 7, mRNA & BC015857 \\
\hline ACP 18-1 (up) & Homo sapiens small glutamine-rich tetratricopeptide repeat (TPR) containing protein & A)223828 \\
\hline ACP 18-2 (up) & Homo sapiens zinc finger, DHHC-type containing 4 (ZDHHC4), transcript variant 4, mRNA & NM_001134389 \\
\hline ACP 19 (up) & Homo sapiens OK/SW-cl.2 mRNA for ribosomal protein S6, complete cds & AB062123 \\
\hline ACP $20(d n)$ & Homo sapiens latent transforming growth factor & NG_016437 \\
\hline
\end{tabular}

*Up or $\mathrm{dn}$ in parenthesis denotes up-regulated genes and down-regulated genes, respectively.

알려진 면역 억제물질 군으로 분류된 unrelated cyclosporin-binding cyclophilin proteins과 결합한다[14]. 면역세포에 서, 이 FK506- FK506-binding protein과 cyclosporin- cyclosporin-binding cyclophilin 복합체는 calcium-dependant phosphatase clacineurin과 상호작용을 하여 면역반응과 관련된 gene의 발현에 필요한 signaling pathway의 인산화를 방해한다. 반면에 FK506-binding protein-bound rapamycin은 rapamycin 의 kinase target과 상호작용하여 면역억제를 일으키는 cell cycle arrest를 초래한다[15]. FK506-binding proteins은 면역억제제 의 작용을 조절하는 핵심 조절인자로 인식되고 있음에도 불구하고, 줄기세포의 증식활동이라는 측면에서 FK506 binding proteins의 기능적 역할은 특정 짓지 못하고 있다. Saccharin의 줄기세포 증식 활성 증가에 대한 FK506-binding proteins의 자세한 기능은 추후 더 연구가 필요하다.

\section{요 약}

Saccharin (o-benzoic sulfimide)은 1879년에 최초로 합성된 열량이 없는 인공감미료이다. 본 연구에서, 우리는 다양한 인간 암 세포주와 인간 골수에서 유래한 중간엽 줄기세포에 대한 saccharin의 생물학적 활성을 실험해보고자 한다. 4가지 인간 암 세포주(H460, H157, A549, SKOV3)와 쥐암세포(Raw264.7) 그 리고 인간 골수 유래 중간엽 줄기세포에 대한 세포 viability assay 는 3-(4,5-dimethylthiazol-2-yl)-2,5-diphenyltetrazolium bromide (MTT)의 변환을 기초하여 세포독성을 실험하였다. Saccharin을 처리하지 않은 세포와 대조적으로 saccharin을 처리한
세포에서 발현 양상이 달라지는 gene을 찾기 위해, 우리는 $\mathrm{ACP}$ 를 기초로 한 DDRT-PCR을 시행하였다. 모든 실험에 사용된 세포들 은 각기 다양한 saccharin 농도로(0.0, 4.8, 7.2, 9.6, 12.0, 14.4 $\mathrm{mg} / \mathrm{mL}$ ) 48 시간 동안 처리되었다. 그 결과, 48 시간 동안 다양한 saccharin 농도로 처리되면서 saccharin 처리를 하지 않은 암세포 보다 saccharin 처리를 한 암세포에서 대사활성을 지닌 세포의 수 가 감소하는 것을 확인할 수 있었고, 이런 세포 증식의 감소는 농도 가 증가함에 따라 더욱 두드러졌다. 그리고 saccharin에 대한 반응 으로 MSCs에 다른 양상으로 발현이 되는 주목할만한 gene 후보군 이 $2 \%$ agarose gel 상에 16 개 밴드로 나타났고, 7 개는 발현이 증가, 9개는 발현이 감소한 gene으로 보였다. 이 후보군중 하나는 FK506 binding protein gene이다. 이 단백질이 줄기세포의 생장 활성에 어떠한 역할을 하고 있는지는 명확하지 않고 saccharin의 줄기세포 증식 활성 증가에 대한 FK506 binding protein의 자세한 기능은 추후 더 연구가 필요하다.

\section{Acknowledgements: None \\ Funding: None \\ Conflict of interest: None}

\section{References}

1. Tandel KR. Sugar substitutes: health controversy over perceived benefits. J Pharmacol Pharmacother. 2011;2:236-243.

2. Whitehouse CR, Boullata J, McCauley LA. The potential toxicity of artificial sweeteners. AAOHN J. 2008;56:251-259.

3. Mitchell H. Sweeteners and sugar alternatives in food 
technology. 1st ed. Oxford: Blackwell; 2006.

4. Schardt D. Sweet nothings. Nutr Act. 2004;9:8-11.

5. Kim HJ, Kim DI, Yon JM. Effects of Jerusalem artichoke (Helianthus tuberosus L.) extracts on blood glucose and lipid metabolism in STZ-induced diabetic rats. Korean J Clin Lab Sci. 2015;47(4):203-208.

6. Yoon KN, Jang HS, Jin GH. Antioxidant, anti-diabetic, anti-cholinesterase, and nitric oxide inhibitory activities of fruiting bodies of Agaricus brasiliensis. Korean J Clin Lab Sci. 2015;47(4): 194-202.

7. Zurlo J, Squire RA. Is saccharin safe? Animal testing revisited. J Natl Cancer Inst. 1998;90:2-3.

8. Turner SD, Tinwell H, Piegorsch W, Schmezer P, Ashby J. The male rat carcinogens limonene and sodium saccharin are not mutagenic to male Big Blue rats. Mutagenesis. 2001;16: 329-332.

9. Assumpção MHMT, Medeiros RA, Madi A, Fatibello-Filho O. Development of a biamperometric procedure for the determination of saccharin in dietary products. Quimica Nova. 2008;31: $1743-1746$.

10. Food and Agriculture Organization; International Programme on Chemical Safety. Summary of evaluations performed by the Joint Expert Committee on Food Additives. Geneva: ILSI Press; 1999.

11. Kim YJ, Kwak CI, Gu YY, Hwang IT, Chun JY. Annealing control primer system for identification of differentially expressed genes on agarose gels. Biotechniques. 2004;36:424-434.

12. Harding MW, Galat A, Uehling DE, Schreiber SL. A receptor for the immunosuppressant FK506 is a cis-trans peptidyl-prolyl isomerase. Nature. 1989; 341:758-760.

13. Siekierka JJ, Staruch MJ, Hung SH, Sigal NH. FK-506, a potent novel immunosuppressive agent, binds to a cytosolic protein which is distinct from the cyclosporin A-binding protein, cyclophilin. J. Immunol. 1989;143:1580-1583.

14. Bierer BE, Somers PK, Wandless TJ, Burakoff SJ, Schreiber SL. Probing immunosuppressant action with a non-natural immunophilin ligand. Science. 1990;250:556-559.

15. Sigal NH, Dumont FJ. Cyclosporin A, FK-506 and rapamycin: pharmacologic probes of lymphocyte signal transduction. Annu Rev Immunol. 1992;10:519-560. 